\title{
屋上緑化における保水効果と植物の生育状況にバイオ炭混合と セダム混植が与える影響
}

\section{松岡達也 ${ }^{* 1,2)} \cdot$ 土屋一涁 ${ }^{1)} \cdot$ 大黒俊哉 $^{1)}$}

\author{
1）東京大学大学院農学生命科学研究科 Graduate School of Agricultural and \\ Life Sciences, The University of Tokyo \\ 2）清水建設技術研究所（現所属） Institute of Technology, Shimizu Corporation
}

\begin{abstract}
摘要：近年注目されている粗放型屋上緑化は，薄層土壌を用いる特性から導入可能な植物種に制限があること や，集中豪雨時の保水量が僅少である点が問題視されてきた。バイオ炭の土壤への混合とセダムの混植は土壤内 の水分量を高く保つことが報告されているが, 現状では各方法の有効性の検証に留まっている。そこで本研究で は, 両方法を用いた場合の相乗効果を期待し, その組み合わせが植物体の生育状況および保水量に及ぼす影響の 検証を目指した。対象植物としてオジギソウとローズマリーを，セダムとしてシロバナマンネングサを用い，温 室内において乾燥条件下における栽培実験を 16 日間行った。また，バイオ炭の混合率を 0\%，15\%，30\%，60 \%とし, セダム混植の有無で分けて栽培した。その結果, 両方法の組み合わせにより保水量および土潩水分量に 統計的に有意な相乗効果はみられなかった。一方で, 両方法を施した場合でも対象植物の顕著な生育悪化はみら れず，バイオ炭の混合率の増加に応じて保水量が向上した。以上より，両方法により顕著な相乗効果は期待され ないものの, バイオ炭混合により生育悪化を防ぎつつ降雨時の保水量向上が期待されることが結論づけられた。 キーワード : 粗放型屋上緑化, バイオ炭, セダム, 混植
\end{abstract}

MATSUOKA, Tatsuya, TSUCHIYA, Kazuaki and OKURO, Toshiya: The effects of biochar amendment and companion planting with Sedum on water holding capacity and the health conditions of the plants for green roofs

Abstract: Extensive green roofs have benefits of weight and cost reduction for the buildings, though their shallower substrates resulted in fewer options of plant species to introduce and lower water holding capacity. Although previous studies reported that companion planting with Sedums and biochar amendment can improve soil water content, their synergistic effects were not fully clarified. Therefore, this study aimed to reveal the effects of the combination of companion planting with Sedums and biochar amendment on the health conditions of the plants. We cultivated two plant species for green roofs (Mimosa pudica and Rosmarinus officinalis) with/ without Sedum album in a greenhouse under drought condition for 16 days. Additionally, we added biochar at rates of $0,15,30$ and $60 \%$ by volume to the substrates. The results indicated that there were no significant synergistic effects by the combination between soil water content and water holding capacity. However, the health conditions of plants were healthy when biochar was added and/or Sedums were planted together. Additionally, water holding capacity was improved with the increase of biochar application rate. In conclusion, we revealed that although synergistic effects between companion planting with Sedums and biochar amendment would not be induced on green roofs, the effects of biochar amendment can improve water holding capacity without wilting of the plants.

Key word: Extensive green roof, Biochar, Sedum, Companion planting

\section{1.はじめに}

近年，都市域における浸水被害を防止するために，屋上緑 化の浸透面を用いた集中豪雨時の雨水流出抑制効果が期待さ れている ${ }^{10)}$ 。他方で，管理の簡便さや建築物の荷重制限の面 から, 屋上緑化では, 最低限の潅水頻度の下で薄層土壌を用 いて緑化を施す粗放型屋上緑化が用いられることが多い ${ }^{14)}$ が, 土壌厚の限られた条件では保水量を確保することが難し (3)。さらに, 屋上緑化には雨水流出抑制以外にも, 都市に
おける蜜源の確保などの様々な役割が期待されているが, 少 ない潅水頻度で乾燥しやすい条件のもとでは, 導入可能な植 物種の選択肢が僅少であることが指摘されている め, 降雨時に保水しつつ, 降雨や潅水がない期間に土壤中に 水分を維持することが重要になる。すなわち, 薄層土壤を用 いた乾燥条件下において，植物体の生育を良好に保ちつつ， 保水量を向上させる栽培技術の開発が求められている7)。

その方法の一つとして, バイオ炭の土壌への混合が挙げら れる。バイオ炭は木材や竹, もみ殼などを熱融解させて生成 
される軽量な有機炭素系物質で, 多孔質な構造を持つことか ら土壤の保水量を向上させる効果を持つ ${ }^{3)}$ 。既往研究では, バイオ炭の混合により植物種の生存率を向上させ, 雨水流出 効果を向上させる可能性があることを報告している ${ }^{13)}$ 。な お，バイオ炭の混合率の増加によって $\mathrm{pH}$ が上昇すること帛, リンや窒素などの土壤栄養成分, 土壤物理性, 土壤微生物と の相互作用の程度などが変化することが報告されている が ${ }^{19)}$, 本研究ではバイオ炭が保水量の変化が植物体の生育に 及ぼす影響に焦点を絞るものとする。

保水量を向上させるもう一つの方法として, セダムの混植 が挙げられる。既往研究から, セダムの混植により屋上部で 植物の生育が良好に保たれる場合があることが報告されてい る2)。また, この効果は混植による土畩水分量の増加に起因 するとされ，セダムがCAM (Crassulacean acid metabolism）型光合成を行うことで蒸散量が抑制されると共に, カーペット状に成長するセダム自体の土壤被覆により蒸発量 が抑制されることで誘導されると推察されている9)。セダム はコロニーを形成する特性を持ち, 広大な緑被状態の安定的 な確保が困難なため ${ }^{4)}$, その間に蜜源植物を導入する余地が あると考えられる。

上記の通り, バイオ炭混合とセダム混植は異なるメカニズ ムによって土壤水分量および保水量を増加させることから, 両方法を組み合わせることにより，その効果が向上すること が予想される。その相乗効果について検証した研究事例は存 在しないが, 土壤水分量と保水量の改善度を向上させること で, 雨水流出抑制効果と植物体の生育の良好さを効率的に両 立できる可能性がある。よって本研究では, 自然降雨に依存 する薄層土潩を用いた粗放型の屋上緑化を想定し, セダム混 植とバイオ炭混合の組み合わせが土壤の保水効果および植物 体の生育に及ぼす影響を検証することを目的とした。そのた めに, 温室内で対象植物（オジギソウ, ローズマリー）の栽 培実験を行い, 保水量, 植物体の生育状態, 土壤水分量, 植 物体地上部の乾燥重量を測定した。その際, セダム（シロバ ナマンネングサ）混植の有無で分けた上で, バイオ炭を 4 種類 $(0 \%, 15 \%, 30 \%, 60 \%)$ の混合率で加えて栽培を行っ た。 $\mathrm{CaO} ら^{3}$ の研究事例では, バイオ炭を $40 \%$ 以上混合し た場合に保水量の改善効果拉よび植物体の生存率に及ぼす正 の影響が頭打ちになることが報告されている。そこで, バイ 才炭の混合率が $30 \%$ 以下の時は, 両方法を組み合わせるこ とで土壤水分量が増加し, 植物体の生育が良好に保たれると
いう仮説を立てた。

また，湿潤した土壤環境で育苗すると，植物体の成長に伴 い蒸発散に必要な水分量が増加し, 夏季において乾燥ストレ スに対応できず生育が悪化する場合があることが報告されて いる ${ }^{11}$ 。そのため, バイオ炭混合による保水量の改善効果が 過剩な場合, 植物体の生育に悪影響が及ぼされる可能性があ る。そのため, バイオ炭混合による保水効果の向上と植物体 の生育の良好さを両立する栽培条件の解明し, 粗放型屋上緑 化へのバイオ炭の導入に向けた基礎的知見を確立すること を, 本研究のもう一つの目的とした。

\section{2. 材料と方法}

\section{1 植物体の栽培条件}

植物体の栽培と実験は, 全て東京大学生態調和農学機構 （東京都西東京市）の温室内で行った。実験は 2018 年の 8 月 14 日から 9 月 2 日まで行い, 気温, 湿度, 生育光量は自 然条件とした。実験期間中の日平均気温は $21.7^{\circ} \mathrm{C}$ から 31.7 ${ }^{\circ} \mathrm{C}$, 日平均湿度は $44 \%$ から $95 \%$, 日照時間は 0 時間から 12.2 時間であった。植物体は, 縦横 $30 \mathrm{~cm} \times 40 \mathrm{~cm}$ のプラス チックプランター（緑のやさいプランター, リッチェル株式 会社, 富山, 東京) を用いて栽培し, 土壤厚は $10 \mathrm{~cm}$ とし た。排水層として, プランター下部に網目 $2 \mathrm{~mm}$ のナイロ ンシートを敷いた上で，直径 $5 \mathrm{~mm}$ の軽石を敷き詰めた。 バイオ炭を用いて栽培実験を行った $\mathrm{CaO} ら^{3}$ の研究事例を参 考とし, 植物体の栽培には粒子径 $5 \mathrm{~mm}$ 未満の赤玉土（赤 玉土， あかぎ園芸，茨城，日本）と，そのうち体積比 $20 \%$ を有機物（ココナッツ繊維, Berry's Life, 香川, 日本) に 置き換えた混合土猿を用いた。バイオ炭は麥田ら ${ }^{10}$ の既往研 究を参考とし, 常緑樹である樫等を由来とし, $500^{\circ} \mathrm{C}$ で熱融 解された木炭 (みのり炭素, 奈良炭化株式会社, 奈良, 日本) を使用した。バイオ炭はふるいで $2 \mathrm{~mm}$ 未満の粒子とし, 体積比 $0 \%, 15 \%, 30 \%, 60 \%$ の割合で混合した ${ }^{3)}$ 。バイオ 炭の各混合率による土壤配合の体積比および土壤要素は表 -1 に記した通りである。

対象植物として，オジギソウ (Mimosa pudica) およびロー ズマリー（Rosmarinus officinalis 'Prostratus') を用いた。 これらの種は日本国内の訪花昆虫の有力な蜜源とされ ${ }^{15)}$, 屋 上緑化に導入することで, 花粉媒介や蜜供給などを介した生 態系サービスの向上が期待される ${ }^{18)}$ 。また, 混植種としてセ ダム緑化への導入を検討する際，セダムとの空間を巡る種間

表-1 植栽区毎の土壤配合条件と土壤要素

Table 1 Soil mixture conditions and soil factors of the substrates

\begin{tabular}{|c|c|c|c|c|c|}
\hline バイオ炭混合率 & 赤玉土 & $\begin{array}{l}\text { 率 (体積上 } \\
\text { バイオ炭 }\end{array}$ & ココナッツ繊維 & $\mathrm{pH}$ & $\mathrm{EC}(\mathrm{mS} / \mathrm{cm})$ \\
\hline $0 \%$ & $80 \%$ & $0 \%$ & $20 \%$ & 5.14 & 0.32 \\
\hline $15 \%$ & $68 \%$ & $15 \%$ & $17 \%$ & 5.67 & 0.37 \\
\hline $30 \%$ & $56 \%$ & $30 \%$ & $14 \%$ & 6.21 & 0.41 \\
\hline $60 \%$ & $32 \%$ & $60 \%$ & $8 \%$ & 7.28 & 0.49 \\
\hline
\end{tabular}


競争を避けつつ裸地を減らす必要がある。そのため, 上記の 蜜源植物のうち生育初期に直立状に成長し，後に匍匐性とな る生育特性を持つ植物種として, 日本の栽培環境でも生育可 能なオジギソウおよび匍旬性のローズマリーを選定した。才 ジギソウは 200 穴タイプの育苗トレーを用いて種子から， ローズマリーは直径 $10.5 \mathrm{~cm}$ の育苗ポットを用いて苗から栽 培し, 育苗開始から50 日後に実験用プランターに移植し た。また, 対象植物と混植するセダムとして, 既往研究で混 植の有効性が示されているシロバナマンネングサ (Sedum album）を用いた9)。シロバナマンネングサは挿木苗から栽培 し, 直径 $6 \mathrm{~cm}$ の育苗ポットを用いて 40 日間栽培した後に 実験用プランターに移植した。植栽区は，プランターの中心 部に 1 個体の対象植物を植える単植区と，その周囲にセダ ムを植える混植区の 2 パターンとした。単植区においては, 小型のプランターを用いて栽培実験を行う特性上，対象植物 同士の種内競争の影響を排除するために植栽数は 1 個体と 設定した。混植区ではシロバナマンネングサを 8 個体植え, 対象植物との間に $7 \mathrm{~cm}$ 以上の間隔を設けた²。シロバナマ ンネングサの草丈 $3 \mathrm{~cm}$ 未満で, カーペット状に成長した個 体を用いた。また，各植栽区とも繰り返しは 6 回とした。

育苗期間中は，自動潅水装置を用いて毎日十分な潅水を 行った。植物体の急激な乾燥ストレス受容を避けるため, 2018 年 8 月 1 日から 8 月 14 日の間は 4 日毎に潅水を行い, 乾燥実験は同年 8 月 14 から同年 8 月 30 日の間に行った。 実験期間は，本研究と同様に排水性の高い土とバイオ炭を用 いた既往研究 排除する ${ }^{19}$ 目的も合わせて決定した。なお，乾燥実験前の対 象植物では葉の萎れは全くみられず，全個体の生育が良好に 保たれていた。実験期間中の潅水間隔は 8 日毎に行い，こ れは 2017 年度の 7 月から 9 月の間に平均で 7.6 日毎に 10 $\mathrm{mm}$ 以上の降雨がみられたことや, $\mathrm{CaO}$ ら $^{33}$ の研究事例にお いて最終萎れ点となる期間を参考とし，設定した。また，潅 水量は $10 \mathrm{~mm}$ 降雨相当となる $1200 \mathrm{ml}$ とし, プラスチック 製ポットを用いて 30 秒掛けて土壤表面に水を脚ける手法を 採用した7”。

2.2 測定手法

保水量は Lundholm ら $ら^{7)}$ の手法を参考とし，実験開始日で ある 2018 年 8 月 14 日に潅水前の重量と潅水 30 分後の重量 差から評価した。
対象植物の生育状態および土壤水分量は, 実験終了の前日 である 2018 年 8 月 29 日に測定した。植物体の生育状態と して, 目視による葉の萎れ具合から評価する生育スコアを用 いた9)。生育スコアは以下の 5 段階により評価した（5：全 ての葉が健康な状態, $4: 30 \%$ 未満の葉の色素が欠落した状 態， $3: 30 \%$ から $70 \%$ の葉の色素が久落した状態，2:70\% 以上の葉の色素が久落した状態, 1 : 全ての葉が枯死した状 態)。土壤水分量は HH2 土壤水分計 (Delta-T Devices 株式 会社，ケンブリッジ，イギリス）を用い，針センサーにより 表層部から $5 \mathrm{~cm}$ 部分の水分量を植栽区あたり 4 点測定し， その平均值をデータとして用いた 2018 年 9 月 3 日に対象植 物の地上部を刈取り, $70^{\circ} \mathrm{C}$ で 7 日間乾燥させた後にその重 量を測定した ${ }^{9.12)}$ 。

\section{3 統計処理}

全ての実験結果は R studio (3.2.3)を用いて統計処理を行っ た。保水量と土壤水分量については, Two-way ANOVAによ りバイオ炭の混合率の違いおよびセダム混植の有無による交 互作用の有無を検定した後に, $t$ 検定または Tukey-Kramer 法により対象值における有意差の解析を行った。

また，生育スコアおよび乾燥重量に関してはノンパラメト リックな解析を行う必要があるため二元配置の分散分析を行 わず5)，バイオ炭の混合率掞よびセダム混植の有無が異なる 全植栽区間において Steel-Dwass 法により対象值における有 意差の解析を行った。

\section{3. 結果と考察}

保水量について Two-way ANOVAを行った結果, 対象植 物の両種においてバイオ炭混合率の違いとセダム混植の有無 による有意な交互作用はみられなかった（オジギソウ $p=$ 0.97，ローズマリー $p=0.87)$ 。そのため, バイオ炭混合率と セダム混植の有無のそれぞれに焦点を当て, 各々 $t$ 検定と Tukey-Kramer 法により解析を行った結果, バイオ炭混合率 の違いにより保水量に有意差が確認された（表-2）。両種と も，バイオ炭を $15 \%$ 以上加えることで非混合時よりも顕著 な保水量の増加がみられること，バイオ炭を $30 \%$ 以上加え ることで更なる保水量の改善効果がみられることが示され た。なお，バイオ炭を $60 \%$ 混合した場合, $30 \%$ 混合時と保 水量に有意差は見られなかった (表-2)。Cao ら ${ }^{3}$ の既往研究 の結果も本研究と同様の傾向を示しており, 体積比 $30 \%$ ま

表-2バイオ炭混合とセダム混植が保水量に及ぼす影響

Table 2 Effects of biochar application and companion planting with Sedum on water holding capacity

\begin{tabular}{|c|c|c|c|c|}
\hline \multirow{2}{*}{ バイオ炭混合率 } & \multicolumn{2}{|c|}{ オジギソウ } & \multicolumn{2}{|c|}{ ローズマリー } \\
\hline & 単植区 & 混植区 & 単植区 & 混植区 \\
\hline $0 \%$ & $0.74(0.04) \mathrm{a}^{*}$ & $0.77(0.06) \mathrm{a}$ & $0.78(0.06)$ & $0.77(0.04)$ \\
\hline $15 \%$ & $1.05(0.03) \mathrm{b}$ & $1.06(0.05) \mathrm{b}$ & $1.07(0.08) b$ & $1.09(0.07) b$ \\
\hline $30 \%$ & $1.17(0.04) \mathrm{c}$ & $1.19(0.01) \mathrm{c}$ & $1.18(0.04)$ & $1.16(0.03)$ \\
\hline $60 \%$ & $1.19(0.01) \mathrm{c}$ & $1.20(0.01) \mathrm{c}$ & $1.19(0.01)$ & $1.19(0.01)$ \\
\hline
\end{tabular}

※括弧（）内は標準誤差を表す。異なるアルファベットは，条件毎にバイオ炭混合率の違いにより $5 \%$ 水準で有意差がみられた ことを表す。 
ではバイオ炭混合率に依存して保水量が増加するものの，そ れ以上の混合率では保水量の改善効果の増加は鈍化するもの と推察された。また, セダム混植により保水量に有意差はみ られなかった。これは, 同様の手法により保水量を評価した Lundholm ら ${ }^{7)}$ の結果を支持するものであり，30 秒間で潅水 を行う特性上，植物体の有無が保水量に及ぼす影響が僅少で あったためと推察された。

土壤水分量については, Two-way ANOVAを行った結果, 対象植物の両種においてバイオ炭混合率の違いとセダム混植 の有無による交互作用がみられた（オジギソウ $p<0.05$, ローズマリー $p<0.01)$ 。そのため, 全植栽条件を対象に当 てて Tukey-Kramer 法により解析を行った結果，両種共にバ イオ炭を加えない条件でのみセダム混植時の方が単植時より も土壤水分量が有意に高く, バイオ炭混合時はセダム混植の 有無で顕著な差はみられなかった（図-1）。セダム混植によ る土壤水分量の増加は，セダム特有の CAM 型光合成による 蒸発散抑制に起因するとされるが9), CAM 型光合成は乾燥 条件下で誘導されることが報告されている ${ }^{1)}$ 。そのため, バ イオ炭混合により保水量が増加した条件においては土壤が乾 燥した状態にならず，混植したセダムが $\mathrm{C}_{3}$ 型光合成を行う ことが予想される。その場合, セダム混植による蒸散量の抑 制がみられず, 結果として土壤水分量が増加しなかったと推 察された8)。得られた結果から, セダム混植の効果は土䁃水 分環境によって異なり, 特に土壤が乾燥した条件でのみ顕著 に誘導されることが示唆された。加えて, バイオ炭混合時に おいても, 本研究よりも乾燥条件に置かれる期間が長い場合 は，七ダム混植により土壤水分量が増加する可能性が考えら れた。また，バイオ炭の混合率に依存する効果に注目する と, 混合率の上昇に応じて土壤水分量の増加がみられた(図1)。これは, バイオ炭を混合することで保水量が増加したた めと推察された ${ }^{3)}$ 。さらに, 保水量に有意差がみられなかっ た (表-2) にも関わらずバイオ炭 $60 \%$ 混合時の方が $30 \%$ 混 合時よりも土壤水分量が有意に高かったのは，育苗期間の生 育初期における保水能力の差に起因するものと推測された。
一方で, 生育スコアおよび乾燥重量については, SteelDwass 法で解析した結果, バイオ炭混合率の違いとセダム 混植の有無によって顕著な差はみられなかった（図-2, 図3)。七ダム混植により対象植物の生育および成長の程度に顕 著な差がみられなかった要因として, 実験期間の長さが考え られる。本研究では 16 日間の栽培試験を行ったが, Vasl ら ${ }^{16)}$ はセダム混植の効果が 1 ケ月以上の実験期間を経た後に みられる場合があることを報告している。そのため，1 月 を越える長期間セダムを混植することで, 植物体の葉が萎れ る時期を遅延させ，生育が良好に保たれることが予想され る。また, バイオ炭非混合時にのみセダム混植による土壤水 分量の増加がみられた結果（図-1）からも，七ダム混植は長 期間かつ強い乾燥条件下において植物体の生育を良好に保 ち, 土壤水分量を高く保つ補助的な効果を持つことが期待さ れる。

上記の通り，バイオ炭を混合した際，その混合率に依らず 対象植物の顕著な生育悪化はみられなかった(図-2, 図-3)。 これは, バイオ炭混合による保水量の増加が顕著であり, 植 物体が成長しても土壤水分量が永久しおれ点を下回らなかっ たためと推察された 割合で混合した場合においても, 顕著な生育悪化を防ぎつ つ, 高い雨水流出抑制効果を期待できる可能性が示唆され た。一方で, バイオ炭を混合すると $\mathrm{pH}$ が上昇すること ${ }^{13}$ か ら，アルカリ性土壤を好まない植物種を緑化に用いる際は， バイオ炭の混合率を上げ過ぎないよう注意が必要である。反 対に, バイオ炭を 4 ケ月以上混合するとバイオ炭の酸性化 に伴い土䁃の $\mathrm{pH}$ が低下することが報告されている ${ }^{19)}$ 。その ため, バイオ炭を土壤に長期間混合する場合は $\mathrm{pH}$ 調整を頻 繁に行う必要があると考えられる。

また，バイオ炭混合時は保水量が大幅に増加したことから (表-2), 本研究で採用した混合率においてはバイオ炭混合 により顕著な雨水流出防止効果が期待されることが示唆され た。その定量的な効果の例として, 土壤にバイオ炭を体積比 $30 \%$ 混合すると, 保水量はオジギソウで 1.61 倍, ローズマ
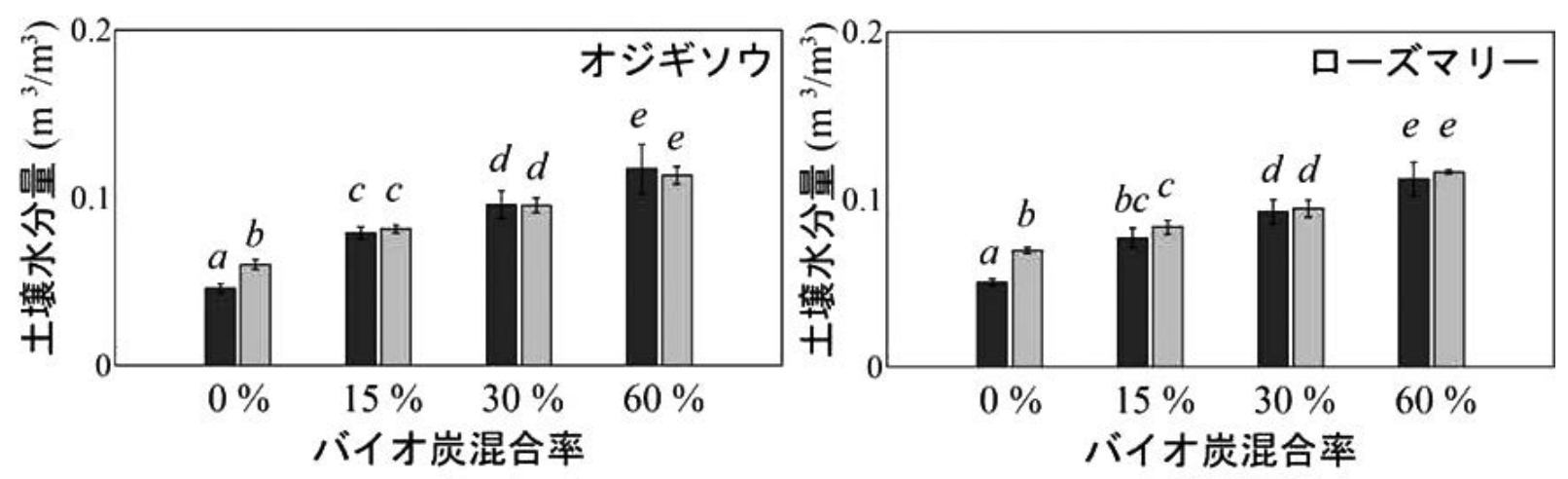

\section{単植区 $\square$ 混植区 ※エラーバーは標準誤差を表し、 \\ 異なるアルファベット間では5％水準で有意差がみられた。}

図-1 バイオ炭混合とセダム混植が土壤水分量に及ぼす影響

Fig. 1 Effects of biochar application companion planting with Sedum on soil water content 

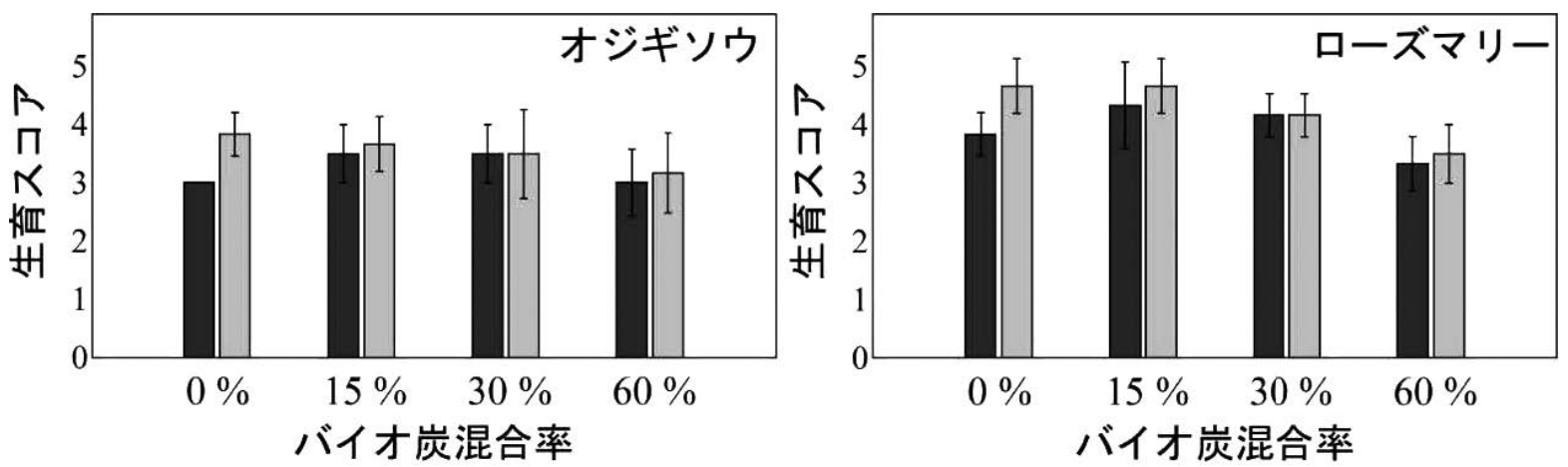

単植区 $\square$ 混植区 ※エラーバーは標準誤差を表し、

異なるアルファベット間では $5 \%$ 水準で有意差がみられた。

図-2 バイオ炭混合とセダム混植が蜜源植物の生育に及ぼす影響

Fig. 2 Effects of biochar application and companion planting with Sedum on the health conditions of nectar-producing plants
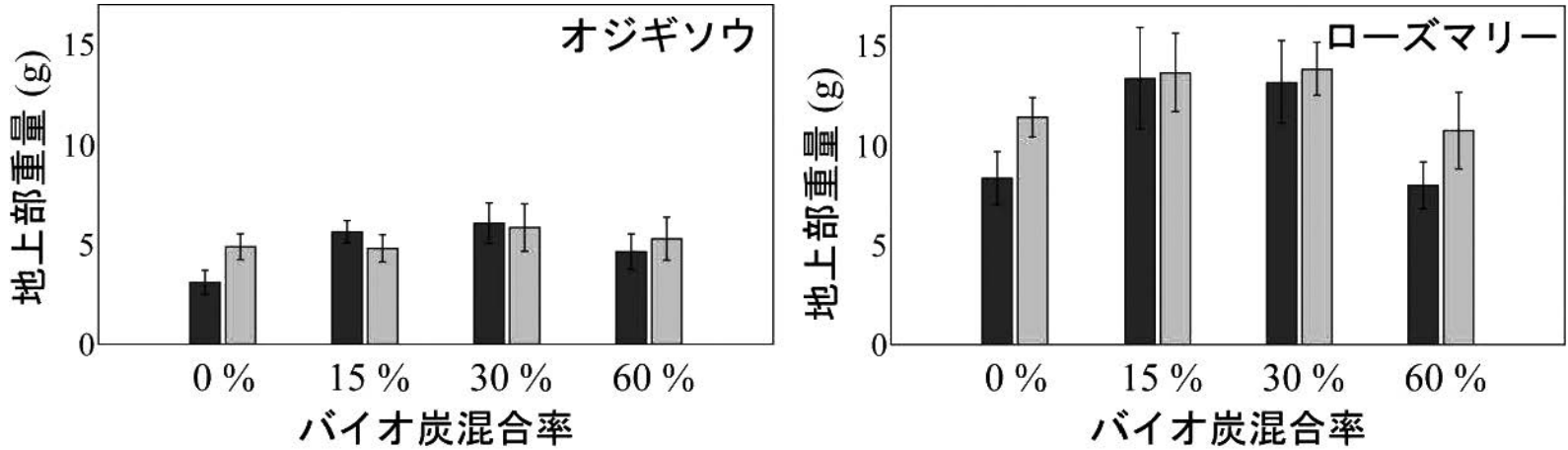

\section{単植区 $\square$ 混植区 ※エラーバーは標準誤差を表す。}

図-3 バイオ炭混合とセダム混植が植物体の地上部重量に及ぼす影響

Fig. 3 Effects of biochar application and companion planting with Sedum on dry shoot weight of nectar-producing plants

リーで 1.51 倍，非混合時と比較して向上することが示され た。他の園芸資材を用いて土壤の保水効果に及ぼす効果を検 証した事例に注目すると, Young $ら^{17}$ は市販の水溶性合成樹 脂を体積比 $1 \%$ の割合で土壤に混合すると, 通常時より保水 量が 1.56 倍に向上することを報告している。よって本研究 の結果から，有機素材であるバイオ炭を用いても，人工的な 保水材と同等の保水効果の向上が期待できると推察された。

\section{4. 結 論}

本研究では，バイオ炭混合とセダム混植を組み合わせ，対 象植物の生育状況および保水効果に及ぼす影響を評価した。 その結果，バイオ炭混合とセダム混植の両方法の導入による 顕著な相乗効果はみられないことが示唆された。一方で，バ イオ炭を体積比 $15 \%$ 以上混合した場合は保水量が大幅に増 加し，かつ対象植物の過度な生育悪化も見られなかった。こ れらの結果から，バイオ炭混合は生育悪化を防ぎつつ雨水流 出抑制を可能にする有効な方法であることが示された。今後
は, 実験期間に依存するセダム混植の効果を検証すると共 に, 土壤栄養や土壤物理性など土壤水分環境以外の要因が植 物体の生育や保水効果に及ぼす影響を明らかにすることで, バイオ炭混合の有効性を解明する必要があると考える。

謝辞：本研究は公益財団法人都市緑化機構の調查研究助成を 頂いて遂行されたものである。また，実験にあたり東大生態 調和農学機構の皆様には多大なご助力を頂いた。この場を借 りて深い感謝の意を表する。

\section{引用文献}

1) Black, C.C. and Osmond, C.B. (2003) Crassulacean acid metabolism photosynthesis: 'working the night shift'. Photosynthesis Research 76: 329-341.

2) Butler, C. and Orians, C.M. (2011) Sedum cools soil and can improve neighboring plant performance during water deficit on a green roof. Ecological Engineering 37: 17961803. 
3) Cao, C.T.N., Farrell, C., Kristiansen, P.E. and Rayner, J.P. (2014) Biochar makes green roof substrates lighter and improves water supply to plants. Ecological Engineering 71: 368-374.

4）飯島健太郎（2003）芝生による屋根緑化（脱セダム屋根） と熱環境の改善, 芝草研究, 32 (supplement 1): 1-8.

5）池田郁夫（2013）統計検定を理解せずに使っている人のた めにIII. 化学と生物, 51(7): 483-495.

6）亀山幸司・岩田幸良・佐々木康一・成岡道男 - 宮本輝仁 （2016）樹皮由来バイオ炭の砂丘地圃場への施用による土 壤の保水性 - 保肥性改善効果. 農業農村工学会論文集, $301(84-1)$ : 65-74.

7) Lundholm, J., MacIvor, J.S., MacDougall, Z. and Ranalli, M. (2010) Plant species and functional group combinations affect green roof ecosystem functions. PLoS ONE 5(3): e9677.

8）松岡達也・土屋一涁・大黒俊哉（2017）屋上緑化に用いら れるセダム類の葉の形質の違いが蒸発散量に及ぼす影響. $43(1): 115-120$.

9) Matsuoka, T., Tsuchiya, K., Yamada, S., Lundholm, J. and Okuro, T. (2019) Value of Sedum species as companion plants for nectar-producing plants depends on leaf characteristics of the Sedum. Urban Forestry and Urban Greening 39: $35-44$.

10）麥田隼希 · 土屋一涁 - 松岡達也 - 山田 晋 · 大黒俊哉 （2018）屋上緑化の雨水流出抑制機能に植物種の違いとバ イオチャーの利用が与える影響. 日本緑化工学会誌, 44 (1): 69-74.

11) Nagase, A. and Dunnett, N. (2011) The relationship between percentage of organic matter in substrate and plant growth in extensive green roofs. Landscape and Urban Planning 103(2): 230-236.
12) Nagase, A. and Dunnett, N. (2012) Amount of water runoff from different vegetation types on extensive green roofs: Effects of plant species, diversity and plant structure. Landscape and Urban Planning 104: 356-363.

13）中根周歩 - 皮玲（2009）屋上緑化土壤への竹炭埋設が植栽 植生の生育に及ぼす効果. 環境情報科学論文集, 23: 441446.

14) Oberndorfer, E., Lundholm, J., Bass, B., Coffman, R.R., Doshi, H., Dunnett, N., Gaffin, S., Köhler, M., Liu, K.K.Y. and Rowe, B. (2007) Green roofs as urban ecosystems: Ecological structures, functions, and services. BioScience 57(10): 823-833.

15）佐々木正己（2010）蜂からみた花の世界四季の蜜源植物 とミツバチからの贈り物. 海游舎, $416 \mathrm{pp}$.

16) Vasl, A., Shalom, H., Kadas, G.J. and Blaustein, L. (2017) Sedum-Annual plant interactions on green roofs: Facilitation, competition and exclusion. Ecological Engineering 108: 318-329.

17) Young, T.M., Cameron, D.D. and Phoenix, G.K. (2017) Increasing green roof plant drought tolerance through substrate modification and the use of water retention gels. Urban Water Journal 14(6): 551-560.

18）山田順之・曽根佑太・古谷勝則（2011）都市域の自然体験 活動としてのミツバチプロジェクトに関する研究. ランド スケープ研究, 74(5): 585-590.

19) Yu, H., Zou, W., Chen, J., Chen, H., Yu, Z., Huang, J., Tang, H., Wei, X. and Gao, B. (2019) Biochar amendment improves crop production in problem soils: A review. Journal of Environmental Management 232: 8-21.

(2020 年 5 月 14 日 受理) 